\title{
Geomorphic Processes, Rock Quality and Solid Waste Management-Examples from the Mt. Everest Region of Nepal
}

\author{
Eva Posch1,2, Rainer Bell2, Johannes Thomas Weidinger ${ }^{1,3}$, Thomas Glade ${ }^{*}$ \\ ${ }^{1}$ Department of Geography and Geology, University of Salzburg, University of Salzburg, Salzburg, Austria \\ ${ }^{2}$ Department of Geography, University of Vienna, Vienna, Austria \\ ${ }^{3}$ ERKUDOK Institute, K-Hof Museums, Gmunden, Austria \\ Email: eva.posch@uibk.ac.at
}

Received 10 August 2015; accepted 8 November 2015; published 11 November 2015

Copyright (C) 2015 by authors and Scientific Research Publishing Inc.

This work is licensed under the Creative Commons Attribution International License (CC BY).

http://creativecommons.org/licenses/by/4.0/

(c) (i) Open Access

\begin{abstract}
Sagarmatha National Park and Buffer Zone (SNPBZ) in the Everest region in Nepal is among the most popular destinations for trekking tourism in Nepal. The dramatic growth of the tourism industry has increased pressures on the environment and the National Park is heavily affected by the rapidly growing waste issue. Besides, major mass movements play an important role in the Himalaya and have been observed in SNPBZ. Also, seasonal monsoon floods, debris flows, rock falls, landslides and the creation of glacial lake outburst floods are frequently occurring in the region. This paper explores the reciprocal interactions between the geo-environment and solid waste management in Everest's SNPBZ. Therefore, geological characteristics and geomorphological processes, especially the two large rockslides in Lukla and Khumjung, as well as their consequences for rock quality, climatic and hydrologic conditions, are analyzed and simultaneously connected to the rapidly growing tourism-induced waste issue. Rockslide material shows high porosity and permeability. Thus, we argue that rockslide facies are particularly vulnerable to contamination by waste water and washed out agricultural fertilizers, which pose threats to the population especially in Namche Bazaar but probably also in Lukla. Also, the landfill sites are often affected by geomorphological processes and may consequently contaminate surface and ground water. Results highlight that regional infrastructure planning of landfill sites often collides with the natural features of the geo-environment and often causes harm to human health and the environment. The implications of the results can be applied to similar areas (such as Marsyandi Valley, Kali Gandaki Valley) with special geological characteristics and rapidly growing waste issues.
\end{abstract}

\section{Keywords}

Sagarmatha National Park and Buffer Zone, Rock Slide Facies, Hydrogeology, Landfills,

\footnotetext{
"The ORCID ID of Thomas Glade is http://orcid.org/0000-0001-9676-4416.
}

How to cite this paper: Posch, E., Bell, R., Weidinger, J.T. and Glade, T. (2015) Geomorphic Processes, Rock Quality and Solid Waste Management-Examples from the Mt. Everest Region of Nepal. Journal of Water Resource and Protection, 7, 1291-1308. http://dx.doi.org/10.4236/jwarp.2015.716105 


\section{Tourism-Impact}

\section{Introduction}

The Nepalese Himalaya, with its unique landscape and fascinating peaks, attracts people from all over the world. Since Nepal first opened its borders to foreigners in the 1950s, tourism has grown exponentially. The high influx of tourists has brought many positive and negative impacts to the country. Local people and work-related migrants have benefitted from economic development, international exposure and cross-cultural exchange. However, the dramatic growth of the tourism industry has increased pressures on the environment. In addition to continuous trail degradation, soil loss, deforestation and land use changes, significant amounts of non-biodegradable litter and solid waste have been generated [1] [2].

Among the most popular destinations for trekking tourism in Nepal is Sagarmatha National Park and Buffer Zone (SNPBZ) in the Everest region (Figure 1). The national park, a protected area since the 1970s, is heavily affected by expanding trekking tourism. It serves as an example of tourism-induced environmental problems with the main focus on the rapidly growing waste issues.

Geologic and geomorphologic processes also play a major role in this dynamic system, as erosional processes and topography of the Himalaya are intimately tied to the South Asian monsoon circulation. To unravel the amount of erosion and gain some insights into the activity of geomorphic processes, decadal-scale erosion rates have been inferred from river gauging data, climate records, and landslide inventories (e.g. [3]-[6]). Moreover,

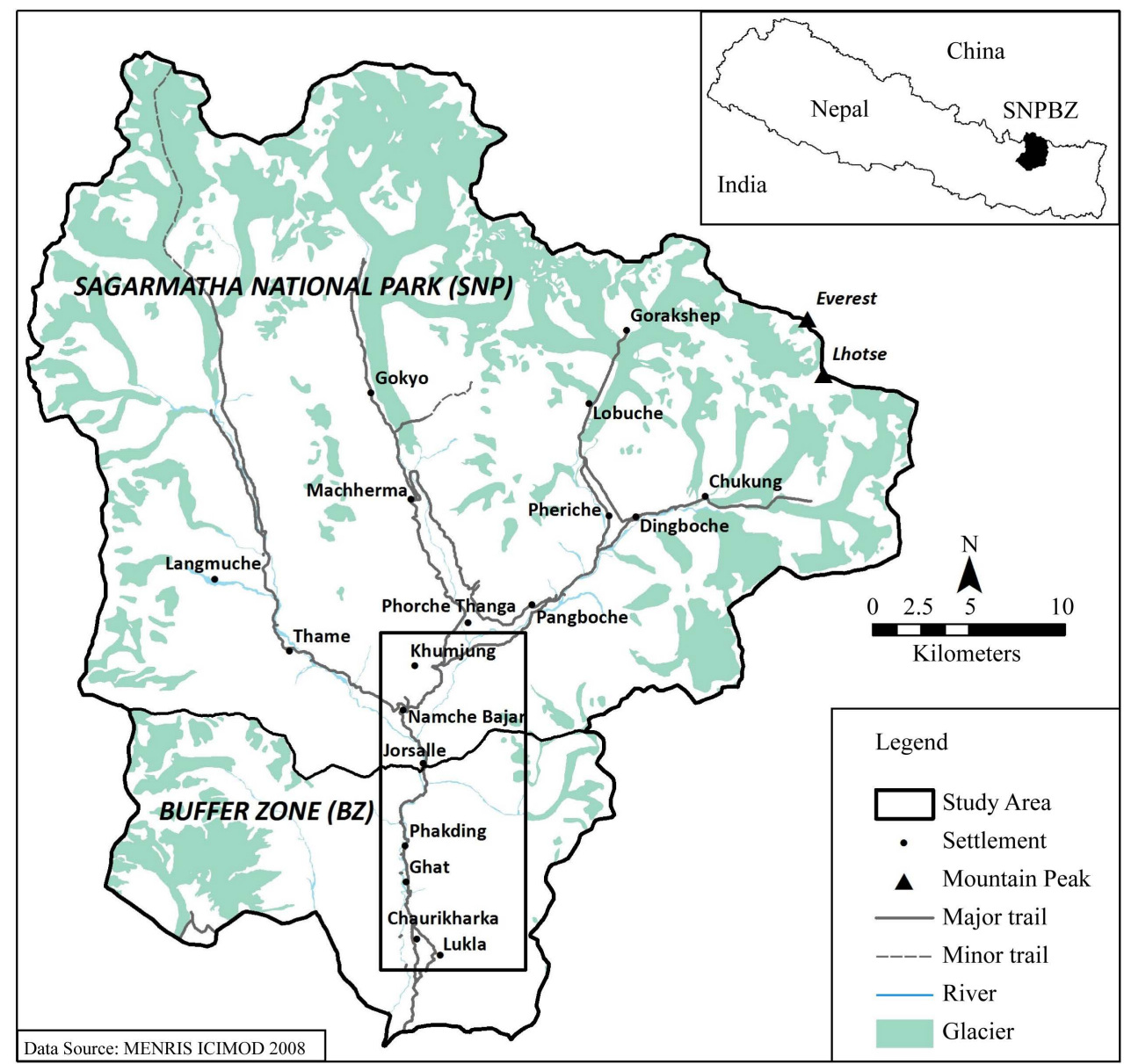

Figure 1. Overview of Sagarmatha National Park and Buffer Zone (SNPBZ) and study area. 
geochemical provenance studies and the use of detrital cosmogenic nuclide concentrations have helped to shed light on millennial-scale natural erosion rates in the High Himalaya (e.g. [7]-[12]).

Furthermore, giant mass movements $\left(>10^{8} \mathrm{~m}^{3}\right)$ play an important role in the Himalayas' landscape evolution across geological time [13]. Evidence of major mass movements has also been observed in the Mt. Everest Region around the villages of Lukla and Khumjung [14] [15]. Such large rockslides often dam rivers and create large lakes, in which sediments are deposited. These landslide dams might fail suddenly causing huge and devastating floods. Beside these processes, seasonal monsoon floods, debris flows, rock falls, creation of glacial lakes due to melting of the glaciers as consequence of global warming and Glacial Lake Outburst Floods (GLOF) are taking place in these environments. Since most mountain areas in the Himalaya are inhabited and tourism is increasing, these processes pose serious hazards to the people [16].

The goal of this study is to investigate the impact of reciprocal interactions between the geo-environment and solid waste management in Everest's SNPBZ. Furthermore, the question whether rockslide facies are particularly vulnerable to waste water contamination is studied. Therefore, geological characteristics and geomorphological processes, especially the two large rockslides in Lukla and Khumjung, as well as their consequences for rock quality, climatic and hydrologic conditions, are analyzed and simultaneously connected to the rapidly growing tourism-induced waste issue. In particular, the location and installation of landfill sites are evaluated and recommendations to improve the situation are derived.

\section{Tourism Development and Waste Generation in SNPBZ}

In the late 1960s, when mountaineering started to flourish in Nepal, tourist numbers began to swell in the Everest region because of improved access, promotion, and publicity (cf. [1] [2] [17] [18]). After the construction of the first airport the tourism economy grew exponentially, from a mere twenty trekkers in 1964 to more than 35,000 in 2012 [19]-[21]. Tourism, ranging from organized or individual trekking groups to professional climbing expeditions, is currently the main source of income and employment for 60 to $80 \%$ of the local population [1] [2]. The standard of living has improved quickly, but has simultaneously led to environmental issues in the fragile alpine environment. Uncontrolled tourism development, which is concentrated both spatially and temporally, is at the heart of the problem [22].

The generation of solid waste due to the high import of packaged consumer goods is one of the major environmental issues in mountain areas with high concentrations of tourism [22]. As the number of tourists increases each year, so does the accumulation of rubbish [1] [2]. The increasing amount of solid waste produced by trekking tourists, mountaineering groups and local shop and lodge owners not only diminishes the attractiveness of the region, but also poses a significant environmental threat to the fragile ecosystem and human health. The consequences include air, soil and water pollution through improper storage and disposal [1] [17] [23]. Solid waste ranges from food packages, wrappers, bottles, glass and metals to hazardous waste items such as batteries, medical supplies and light bulbs. All of these materials accumulate quickly and pose serious disposal problems [23] [24].

The daily average waste generation in SNPBZ is unequally distributed over the year and is dependent upon location. Considering the seasonal pattern of tourism, solid waste amounts to approximately $4.6 \mathrm{t}$ /day during the tourist season to only $2 \mathrm{t}$ /day during the off season [22]. The spatial distribution of waste generation differs widely. Major settlements on the popular Everest Base Camp Trek, such as Namche Bazaar and Lukla, host a high number of lodges and shops and consequently produce more waste [22].

Currently, the government of Nepal has planned to build a new road to ease access to Khumbu Valley. This $100-\mathrm{km}$ road will link Jiri with Surke village (South of Lukla) or even Chaurikharka which is located just north of Lukla (Figure 1). The construction of the road is planned to start until April 2015 [25]. Beside the benefits for the tourism industry and locals this new road probably will lead to an increase in number of tourists and intensify the waste generation and management issue.

\section{Methods}

This study is based on geological and geomorphological mapping as well as petrographic analysis, extensive literature review and hydrologic data analysis. The two very large rockslide areas were mapped and special petrologic features detected, which are most important to recognize rockslide rudiments after overall erosion processes. Samples from basal and internal rockslide structures were taken and thin sections prepared in the labora- 
tory and analyzed since this is still the best method to find typical microstructures and to verify paleo-landslideprocesses [26]. Furthermore, locations and installations of landfill sites were mapped and analyzed in combination with the results from the geological-geomorphological analysis. Water samples collected at springs and fountains in Namche Bazaar and Khumjung provided insights to water quality in the region and spatial distribution of aquifers. A Sera test kit was used to measure nitrate and phosphate concentrations. Field work campaigns were carried out in 2007 (March and April), 2011 (July and August) and 2013 (April and May). All relevant information was digitalized and analyzed in a geographic information system (GIS).

\section{Study Area}

The study area, which was limited to the section between Lukla, Namche Bazaar and Khumjung, is situated within the SNPBZ in the northeastern district Solu-Khumbu in Nepal (Figure 1). Lukla is the gateway to the Everest region because it is connected by regular air service. There are several lodges and tourist facilities. Namche Bazaar is the main economic and touristic center of the region and the gateway to various basecamps and mountain peaks. Namche Bazaar has prospered immensely from the tourist trade and belongs to one of the wealthiest villages in Nepal, although it is physically isolated by mountainous terrain [17] [27]. The traditional farming villages Khumjung, Syangboche and Khunde are situated above Namche Bazaar.

The study area includes the world's highest mountain, Mt. Everest ( $8848 \mathrm{~m}$ a.s.l.), and several other peaks above $7000 \mathrm{~m}$ a.s.l. [18] [24]. The Himalayan Mountains are not only the highest in the world but are also amongst the youngest, formed by the most recent continental convergence [28]. The SNPBZ belongs to the "Higher Himalayan Zone" consisting of high-grade metamorphic and weathering-resistant rocks such as gneiss, migmatite, schist, quartzit, and marble [29]. The northern part of the Higher Himalayan Zone is overlain by the Tibetan Sedimentary Sequence. The park is characterized by a rugged terrain of high mountains, glaciers, deeply incised valleys and constricted (glaci-)fluvial terraces. Landslides, mudslides and debris-flows can be observed throughout the SNPBZ due to fragile geology, rugged topography and steep slopes, in combination with intense monsoonal precipitation [30] [31].

In recent years, Himalayan glacial lakes are increasing in number and volume because of the continuous recession of glaciers in the context of climate change (cf. [32]-[34]). Within the span of decades, several GLOFs were experienced in Khumbu: Nare (1977), Dig Tsho (1985), TamPokhari (1998). According to Byers [35], more than 34 lakes appear to be growing in the Khumbu region and more than one third are classified as dangerous. A rupture may cause great destruction to downstream areas, as it would affect the most densely populated and trekked areas in SNPBZ ([31] [36]-[39]).

The Everest Region is strongly influenced by the subtropical Asian monsoon regime in summer months, but by a dry climate with snowfall in winter [29] [30]. Summers are generally moist and cool and, on average, about $80 \%$ of the annual precipitation occurs from late May to mid-September [40]. Khumbu precipitation generally decreases with increasing elevation because of topographic effects [30]. Therefore, the rainfall in the valley bottom is much higher and villages are hit harder by heavy monsoon rains [39]. The regional hydrology is dominated by the monsoonal precipitation regime. Stream flow dynamics of the river system have strong seasonal components, with annual discharge peaking during the monsoon season [41] (Figure 2).

\section{Results}

\subsection{Lukla Rockslide Deposit and Its Rock Quality}

The Lukla rockslide occurred in the paragneis series belonging to the Higher Himalayan Crystalline. It originated from the WSW at NgotungRi peak (3409 m a.s.l.) and movement was to the ENE (Figure 3 and Figure 4) [15] [42] [43].

Outcrops of the landslide deposit are rare, and the overall topography underlines the theory of a departed or polyphase rockslide event: while the deposited mass $\mathrm{N}$ of Chaurikharka have surface topographic and sedimentologic characteristics of a large rockslide with a heavily brecciated basal layer, the southern parts show similar features down in the DudhKosi river gorge, but are there additionally topped by a boulder carapace forming a terrace-like deposit from Chaurikharka to Muse. Between there and Lukla rockslide boulders on top of bedrock and moraine were found, while Lukla itself is located on an alluvial and debris flow fan [15] [42] [43]. South of Lukla bedrock geology is obscured by moraines from the SurkeDrangka Valley and rockslide material is missing [15]. 


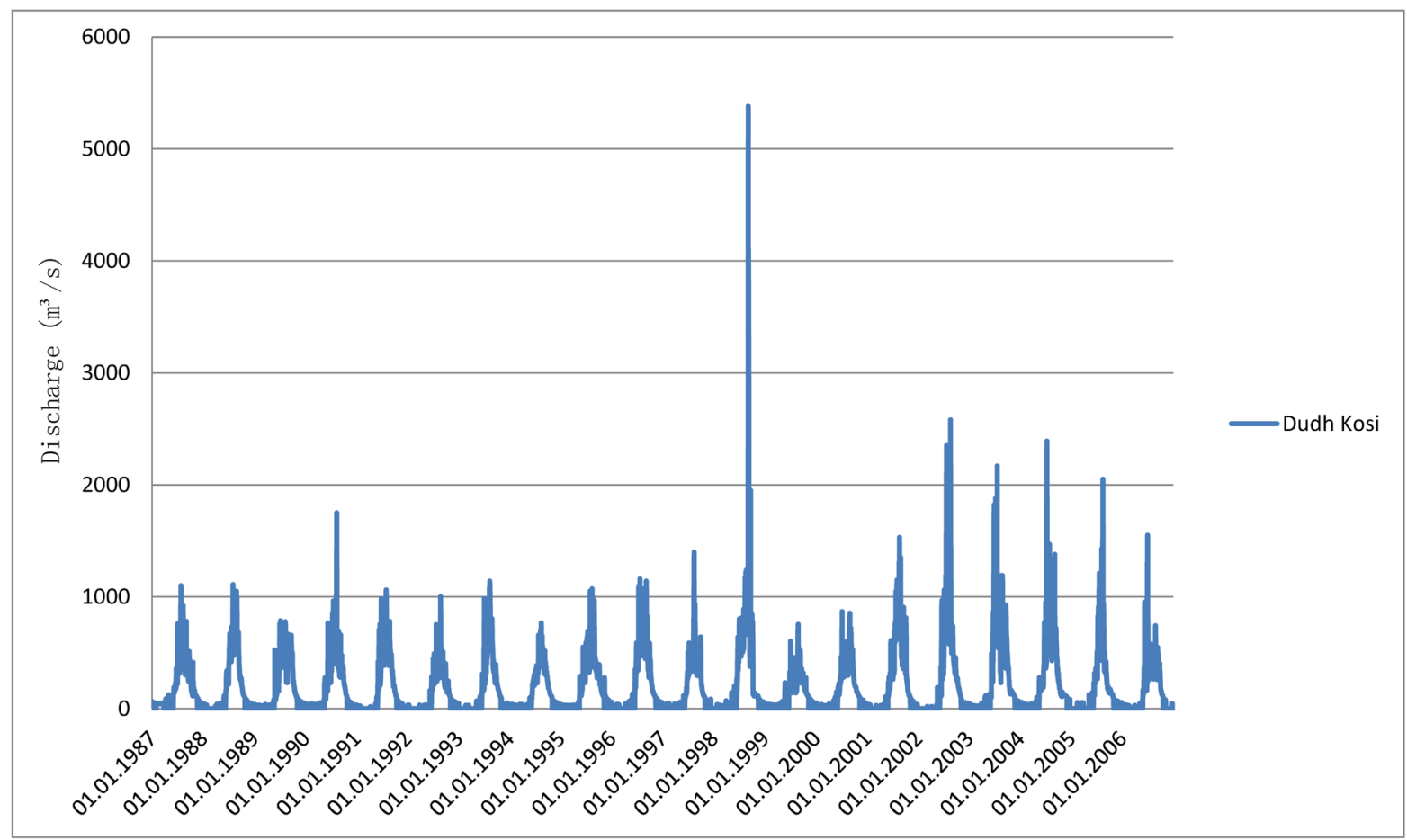

Figure 2. Discharge of Dudh Kosi at Rabuwar-Bazaar, which is located $47 \mathrm{~km}$ south of Lukla and includes major tributaries like the Inkhu Khola and the Hongu Khola. Respective conjunctions are also south of Lukla. Within the subcatchment of Inkhu Khola the Tam Pokhari GLOF, which did not impact our study area, occurred 03-08 September 1998 which started with a peak discharge of about 10,000 $\mathrm{m}^{3} / \mathrm{s}$ [62] (Station: 670; Lattitude: 271600; Longitude: 863950; Source: Department of Hydrology and Meteorology, Nepal).

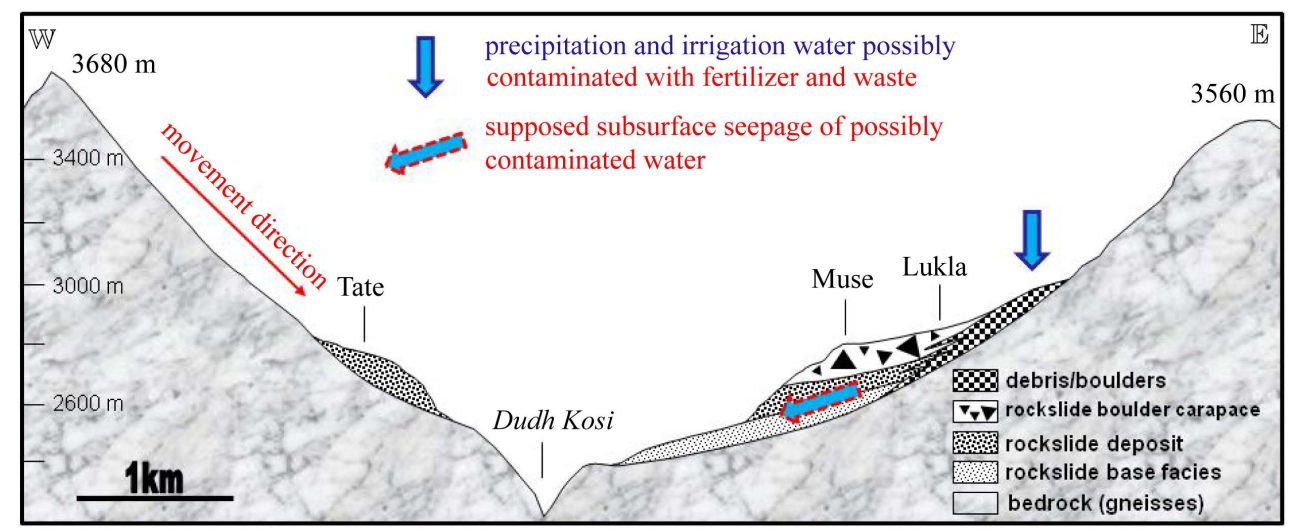

Figure 3. Geologic long-section of Lukla rockslide: supposed subsurface way of seepage of possibly contaminated water due to organic and chemical fertilizer as well as open waste pits.

Key exposures of the basal brecciated facies on top of the basement of granitic gneisses occur in the dissected gorge along the Dudh Kosiriver as well as $1 \mathrm{~km}$ south of Ghat village (2600 m a.s.l.). The brecciated rockslide facies material, which even hosted rockslide-typical micro-brecciae and frictionite [26] [44] [45], is highly susceptible to erosion and porosity, which means that rock quality was significantly altered by the event (Figure 5).

\subsection{Lukla Rockslide's Paleo-Impoundment and Its Sediment Fillings}

The Lukla rockslide formed a natural dam up to $100 \mathrm{~m}$ high, which had blocked the Dudh Kosi river. The so dammed lake must have had a short and eventful lifespan, as: 


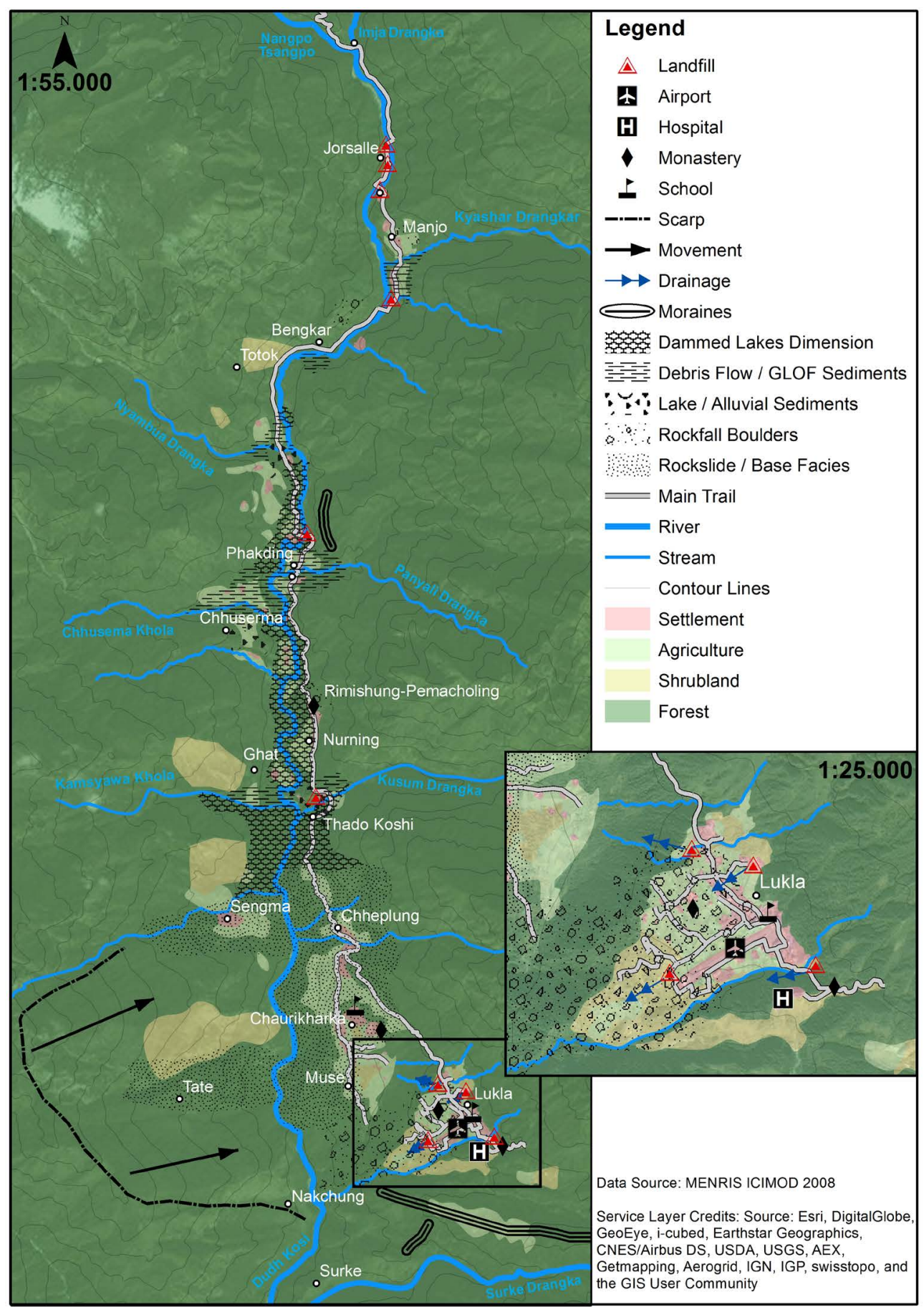

Figure 4. Geologic sketch map of the Lukla rockslide, backwater sediment infill of the Dudh Kosi river and location of landfill sites. Local names according to AGVH [60].

i) outcrops of warved bottom-set lake sediments south of Ghat village indicate its formation over a period hardly exceeding 120 years [45] (Figure 4);

ii) outcrops along its possible former extent, f. i. near Phakding and Chhuserma villages, show a highly heterogeneous mix of lacustrine, fluvial and debris-flow sediments, the latter originated from the Panyali Drangka and Chhusema Khola tributaries at their confluences with Dudh Kosi (Figure 6);

iii) GLOF sediments were found at the Kusum Drangka-Dudh Kosi-confluence as well as south of Manjo vil- 


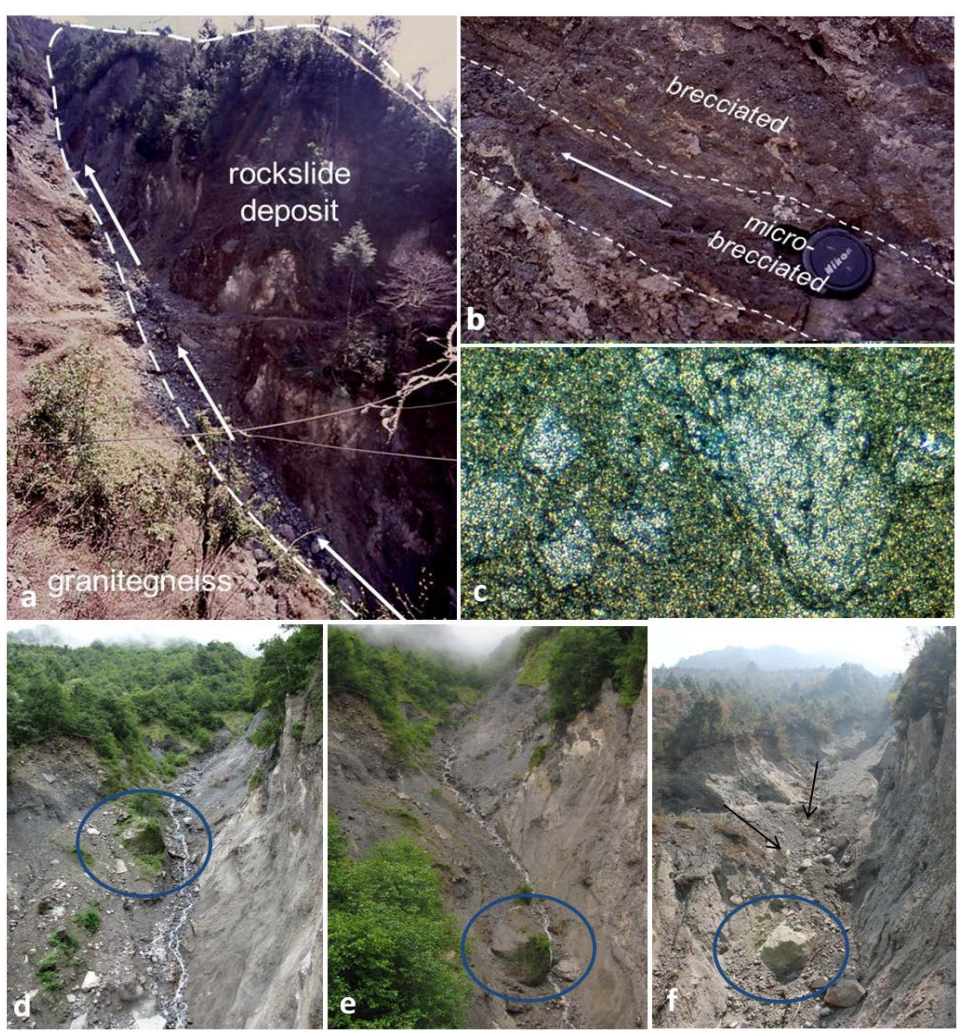

Figure 5. Rockslide base facies, generated by dynamic fragmentation during its catastrophic run out, 1 $\mathrm{km}$ south of Ghat village: View of micro-brecciated sliding surface of the rockslide (b) as well as a thin section (c) of this material showing high porosity and permeability, even in sub-grain-size scale. This cataclastic rockslide material is further more highly susceptible to progressive gully erosion: outcrop in March 2007 (a), in July 2011 (d), in August 2011 (e) and in April 2013 (f).

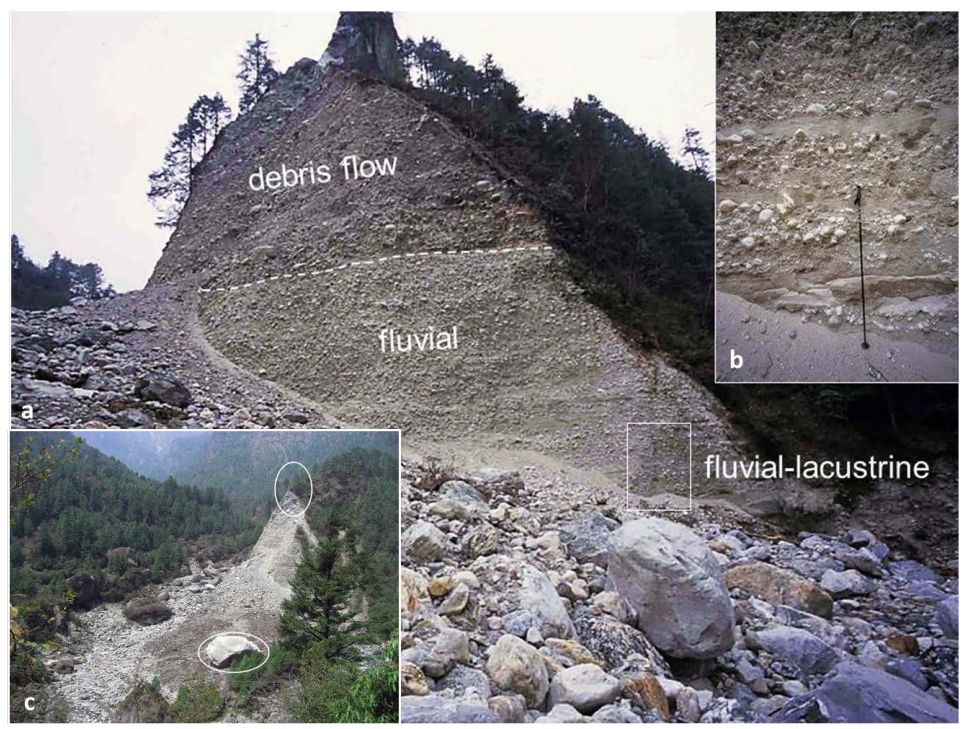

Figure 6. Chhuserma village (2560 $\mathrm{m}$ a.s.l.) is positioned on top of a dissected sediment cone at the confluence of Chusema Khola (western tributary) with Dudh Koshi. The outcropping sediments on its footwall (a, in 2007) demonstrate the rapid infilling of a former lake by fluvial-lacustrine (insert b), fluvial and debris flow sediments. This material is not only subject to high porosity and permeability but also to high morpho-dynamic activity (c, total view in 2013 with large fallen boulder) and therefore problematical for any kind of waste deposition. 
lage, where a fan has terraced gravel extending as far as Bengkar, and would have been formed along KyasharDrangka river by a GLOF from episodically draining moraine-dammed lakes below Kyashar Glacier (Figure 4).

Judging from inset terraces in the gorge and close to Chaurikharka it seems that the rockslide dam of Lukla failed due to overtopping followed by periodic downcutting [45]. The dam is now dissected by a $90-\mathrm{m}$ deep gorge but the river has not jet cut back into bedrock.

\subsection{The GLOF-Problem and Monsoonal Floods in the Upper Catchment of Dudh Kosi}

Most of the identified GLOFs occurred in tributaries of the Dudh Kosi River and have contributed substantially to erosion and sediment transport along this river during discharges that were estimated up to 60 times greater than during meteorological floods changing the landscape seriously [46]. From all potential GLOFs in the SNPBZ the one from Imja Tsho is supposed to be the most dangerous one. A current GLOF risk assessment comes to the conclusion that the initial peak discharge will be almost $6000 \mathrm{~m}^{3} / \mathrm{s}$ with a potential flood height of less than 10 $\mathrm{m}$ throughout the valley. Inside the flood-prone area almost 6000 to 8000 people are likely to be affected [37]. Worst case scenarios are either when such a GLOF occurs during the main tourist season when much more people are in the area or during monsoon period when the GLOF might appear on top of high river discharge, leading to flood heights of more than $10 \mathrm{~m}$.

In the section between Lukla and the confluence of Imja Drangka and Nangpo Tsangpo landslides, torrents, mudflows and debris-flows are still threatening smaller villages, infrastructure facilities and the trekking trail, which mostly runs along the Dudh Kosi river bed on lower terraces before steeply climbing to Namche Bazaar, especially during the monsoon season. As Figure 2 shows, extreme rainfall events during the monsoon season also lead to higher river discharge, causing erosion of slopes and flooding of lower terraces [47] and thus posing threats to landfill sites located on these lower terraces (Figure 7). It is not possible to roughly estimate changes in the water level from the discharge data but it shows how dynamic river discharge is and that the monsoon rainfalls in early 2000s were much stronger than in the late 80 s and 90s (Figure 2). Our own observations show that e.g. at Phakding the river level in the monsoon season (August 2011) was up to $5 \mathrm{~m}$ higher than before the monsoon season (April 2013).

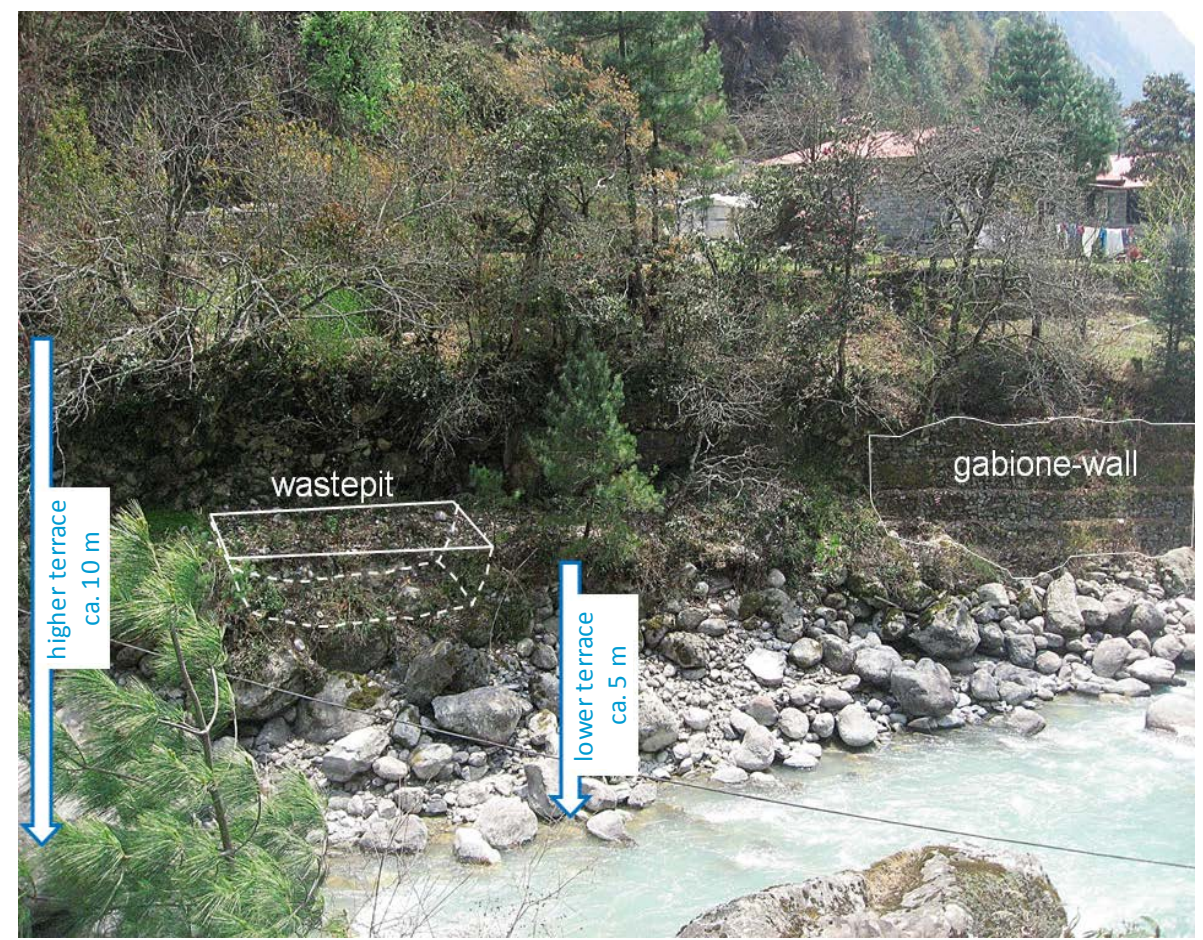

Figure 7. View towards orographic left bank of Dudh Kosi river close to Phakding in April 2013: waste pit in the lower terrace. Constructed gabione-wall shows high susceptibility to erosion even of higher river terrace. 


\subsection{The GLOF-Problem and Monsoonal Floods in the Upper Catchment of DudhKosi}

The Khumjung rockslide is one of the largest known bedrock failures in the Nepalese Himalaya and occurred in the Higher Himalayan Zone within migmatiticorthogneisses, paragneisses and leucogranitic intrusions not far from the South Tibetan Detachment System [14] [42] [43] [48]. The deposit of Khumjung rockslide originated from around the peaks of Khumbi Yul Lha (5761 m and $5200 \mathrm{~m}$ a.s.1.; Figure 8).

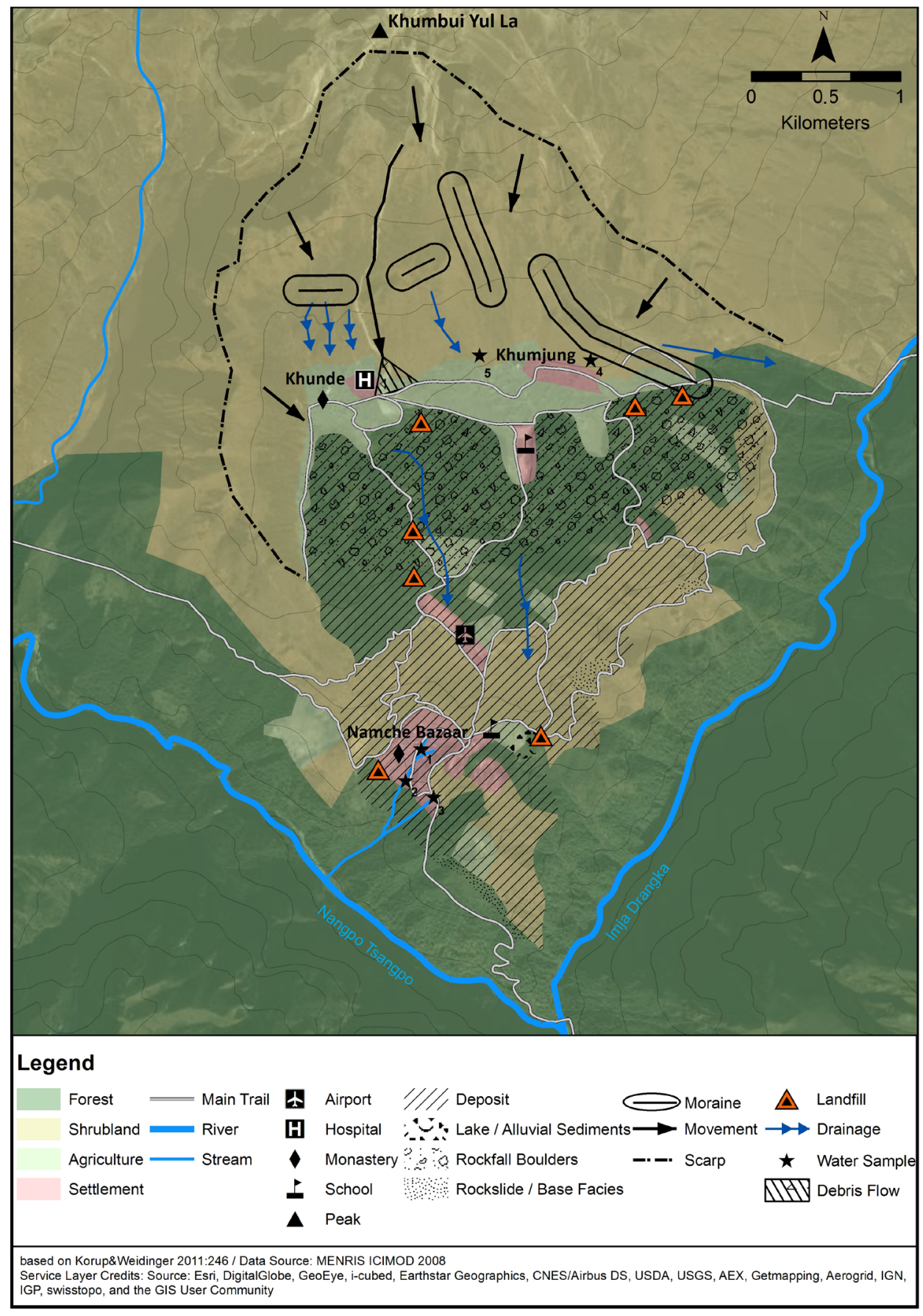

Figure 8. Geologic sketch map of Khumjung rockslide, its geo-hydrologic system and location of landfill sites and water samples: large arrow symbolizes supposed subsurface seepage of possibly contaminated water due to fertilizers and open waste pits from Khumjung towards Namche Bazaar (after [14]). Local names according to AGVH [61]. 
It is likely that the masses detached along one of the major fault-sets in the scarp area with an E-W-strike and a dip $40^{\circ}$ towards S. The southward motion of the rockslide ended up in forming a double terraced platform. Flanked by steep rockwalls towards the river valleys of Nangpo Tsangpo and Imja Drangka, these deeply eroded gorges have undermined the deposit and erased any trace of a former zone of collision or dislocated material. The lower terrace is located $600 \mathrm{~m}$ above these river gorges, and Namche Bazaar, which is located in an eroded "horseshoe-like" basin (Figure 9). While Vuichard [49] found that this basin is cut back into moraine material, it seems to be more likely that this all is rockslide material according to the interpretation following. The upper terrace sustains the villages of Khumjung and Khunde with an overall exposed carapace of large boulders, followed by lake sediments and huge moraines towards $\mathrm{N}$ in the scarp area (Figure 10).

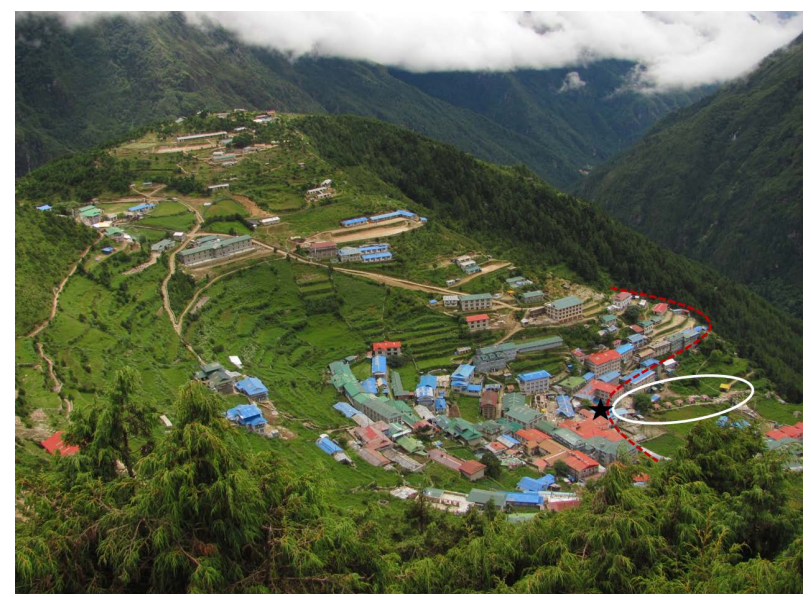

Figure 9. View towards S over "horseshoe terrace" of Namche Bazaar and Dudh Kosi valley: lowermost houses of the settlement mark the base of the rockslide (- - ), ( $\star$ ) marks the main water source, white ellipse mark mills along water runoff on top of mechanically undisturbed bedrock.

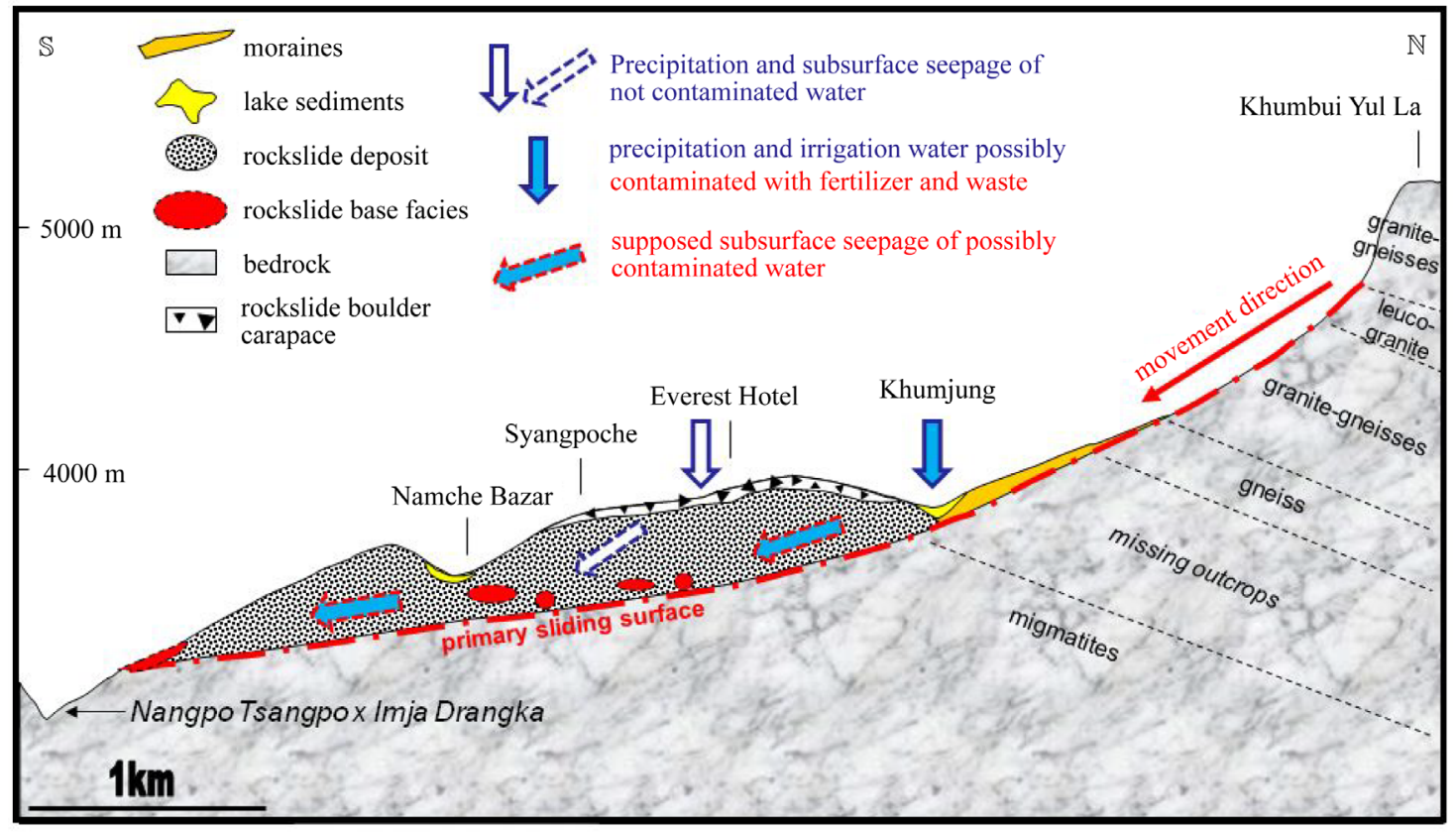

Figure 10. Geologic long-section of Khumjung rockslide (after [14]): supposed subsurface way of seepage of possibly not contaminated and contaminated waters due to organic and chemical fertilizer as well as open waste pits. Remarks: precipitation water dropping down on the rockslide's surface in between Khumjung and Namche Bazaar and seepaging through rockslide material may not necessarily contain high phosphate and/or nitrate as this water bypasses the Khumjung-Khunde agricultural area (compare Table 1, No. 4 and 5). 
A flat area along the trail from Imja Drangka to Namche Bazaar morphologically mimics a lithological difference between shattered, cataclastic and brecciated gneisses and granites with grus-like weathering that mark the base of the rockslide at $\sim 3100$ m a.s.l. (close by First-Everest-View-Point). However, no outcrop of the primary sliding surface could be found. Nevertheless, this diagnostic sedimentology can be followed up to an altitude of $3350 \mathrm{~m}$ a.s.l., hence the rockslide debris must be at least $250 \mathrm{~m}$ thick at this location. The steep, boulder-covered, heavily vegetated, and thus mainly inaccessible terrain of the hillslopes below Namche Bazaar made it intractable to detect further outcrops of the rockslide's basal facies. However, there are several outcrops with facies tell-tale of an origin in close proximity to a rockslide's primary sliding surface along the SE-flank towards Imja Drangka river. The spatial distribution of these outcrops is complex (Figure 10), but strongly fragmented augengneiss and leucogranites were definitely found (Figure 11(a) and Figure 11(b)). It is inferred that the basal contact of the rockslide is now stranded $\sim 250 \mathrm{~m}$ above the present channel floor. So we follow the opinions of Fushimi [50] and Heuberger and Weingartner [48], who suggested an extensive valley glaciation during the last LGM, whilst Iwata [51] and Finkel et al. [52] think of a much lesser maximum glacier extension [53].

The bouldery carapace facies of the rockslide includes the villages of Namche Bazaar, Khunde, and Khumjung, extends over some $400 \mathrm{~m}$ of elevation difference up to $3800 \mathrm{~m}$ a.s.l., and is triangular shaped in planform. This area is covered by angular boulders of diameters up to $10 \mathrm{~m}$, which form longitudinal ridges SE of Khumjung, as well as large hummocks between Syangpoche airstrip and Khunde. Formerly ponded areas with lake sediments south of Khunde and Khumjung mark the boundary to the moraine covered rockslide scarp. This area is predesigned for infiltration of natural and anthropogenic influenced waters (Figure 11(c)).

\subsection{Waste Management Practices}

The existing waste management system in SNPBZ is a rudimentary disposal system with limited resources and capacities, leading to improper treatment of solid waste and waste water. There are different disposal methods for solid waste in SNPBZ. Classified burnable waste (paper, plastics, textiles, plastic bottles) is either burned in incinerators or in open landfill sites to reduce volume, while non-burnable waste (metals, glass, batteries, compact fluorescent lights, medical supplies) is dumped and buried at landfill sites and not handled separately [24] (Figure 12).

The location of landfill sites and incinerators is often poorly chosen. In Lukla, waste is buried on the upper

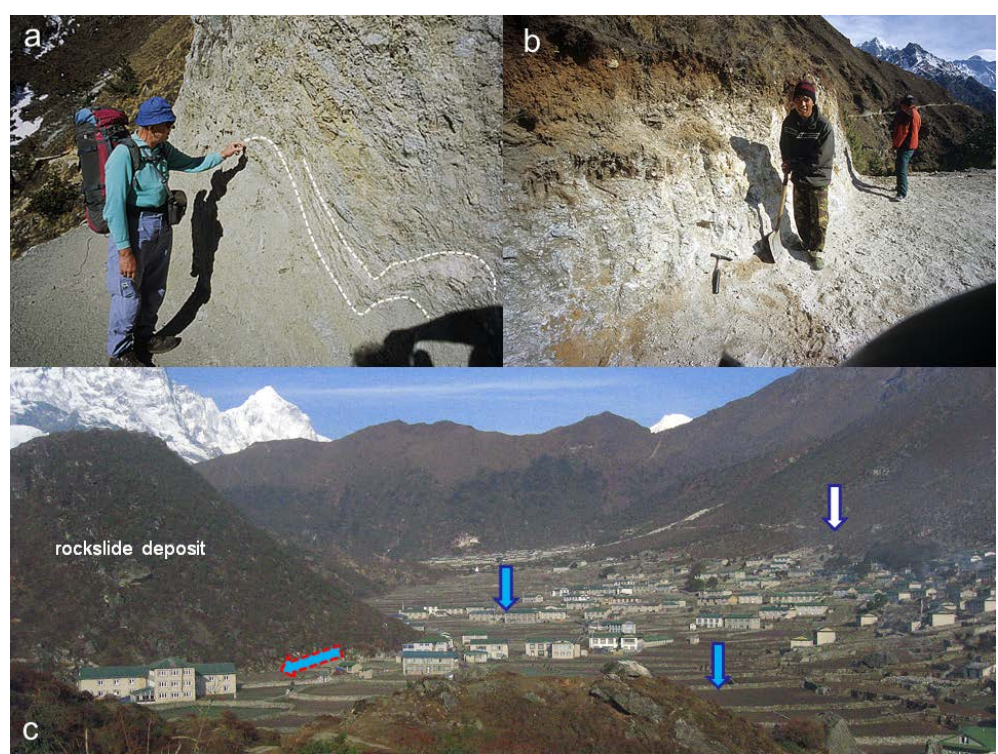

Figure 11. Khumjung rockslide deposit: typical "schlieren-like" deformation of primary rock structure in base facies (a), almost mechanically pulverized material, easily erodible for path workers along main trail to Tengpoche, Imja Drangka valley upwards (b), both positions: $1 \mathrm{~km}$ east of Everest View Hotel (3600 $\mathrm{m}$ a.s.1.); Khumjung and Khunde (in the background) villages-main points of possible water infiltration (colour of arrows see Figure 10). 


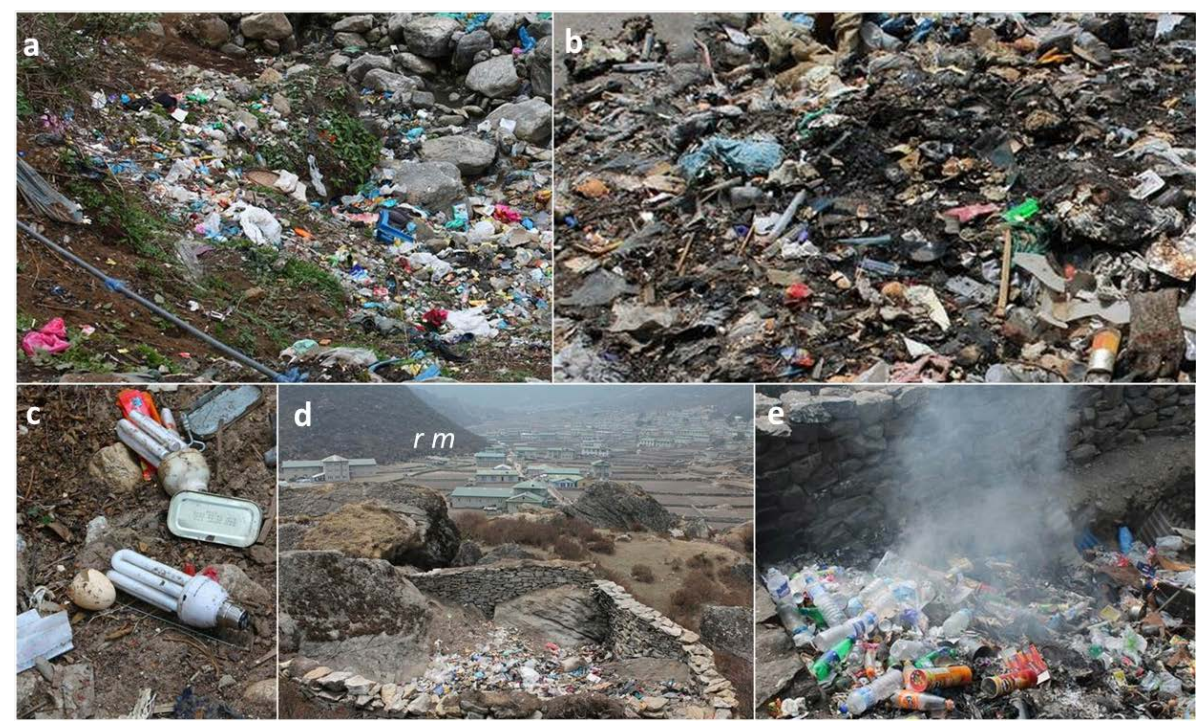

Figure 12. Waste situation in SNPBZ: leaking plastic water pipes (a); medical waste in Lukla e.g. used needles, 2 = broken medicine bottle (b); hazardous Waste Items (c), landfill Sites in Khumjung facing west, rm_rockslide material (d); air pollution caused by toxic gas emission from burning plastics (e).

terrace, above the village and local water supply (Figure 4 and Figure 12(a)). Between Lukla and Namche Bazaar, landfill sites are situated close to seasonal watercourses, streams, rivers and drinking water sources. Waste in Khumjung, Khunde and Syangboche is either taken to designated landfill sites or to illegal dumping pits in forests and on rocky slopes (Figure 12(d)). The landfill sites are situated on the upper terrace, or slopes above Namche Bazaar and its local water supply (Figure 8 and Figure 9).

Water samples of springs and fountains in Namche Bazaar and Khumjung (Figure 9) were collected and analyzed on site. The analyzed water sources were those utilized for drinking water. Results from the Sera test kit show that several springs and streams, particularly in the village of Namche, have high concentrations of nitrates $\left(\mathrm{NO}_{3}\right)$ and phosphates $\left(\mathrm{PO}_{4}\right)$, which are usually used as field fertilizers (see Table 1).

Dumping of medical waste, such as used needles, medicine bottles and pharmaceutical containers occurred within general solid waste and without treatment and was found at a landfill site close to the hospital of Lukla (Figure 1). It is suggested that poor management and disposal of medical waste causes great harm to people's health and the environment, as waste may contain low concentrations of infectious agents or chemical substances [54].

Another serious issue in the whole study area is air pollution caused by toxic gas emission from burning plastics, metallic objects, synthetic materials and hazardous items (Figure 12(e)). Hazardous items include light bulbs, batteries, electrical appliances and gas cartridges, which can be found in large numbers around integrated landfill sites and incineration facilities throughout the study area (Figure 12(c)). It is likely that mercury, $\mathrm{PCDD} / \mathrm{PCDF}$ and other compounds are released into the environment, infiltrating water sources and contaminating the air [22] [24].

\section{Discussion}

The two rockslides featured are the largest known in the Khumbu Himal, and the larger exceeds the size of the largest historic landslide, the 1979 Ama Dablam rock avalanche $\left(10^{8} \mathrm{~m}^{3}\right)$, by an order of magnitude. The Khumjung rockslide is the sixth-largest catastrophic bedrock failure in the High Himalaya of Nepal known to date [13]. Both landslides occurred close to major fault zones. The Lukla rockslide occurred in a paragneiss series as part of the base of the Higher Himalayan Crystalline (HHC) lithotectonic unit in the hanging wall of the Main Central Thrust (MCT). The Khumjung rockslide lies in the upper Higher Himalayan Crystalline, close to the South Tibetan Detachment System (STDS), where massive leucogranitic intrusions crop out in the peak areas of Taboche (6367 $\mathrm{m}$ a.s.1.), Ama Dablang (6856 $\mathrm{m}$ a.s.1.), Lhotse (8501 $\mathrm{m}$ a.s.1.), and Nuptse (7879 $\mathrm{m}$ a.s.1.). The find- 
Table 1. Water samples-Namche Bazaar and Khumjung.

\begin{tabular}{ccccc}
\hline Location & Village & Date & Phosphate & Nitrate \\
\hline No. 1 & Namche Bazaar & $29 / 4 / 2013$ & $0.5 \mathrm{mg} / 1$ & $10 \mathrm{mg} / 1$ \\
No. 2 & Namche Bazaar & $29 / 4 / 2013$ & $0.5 \mathrm{mg} / 1$ & $10 \mathrm{mg} / 1$ \\
No. 3 & Namche Bazaar & $29 / 4 / 2013$ & $1 \mathrm{mg} / 1$ & $10 \mathrm{mg} / 1$ \\
No. 4 & Khumjung & $28 / 4 / 2013$ & $0 \mathrm{mg} / 1$ & $0 \mathrm{mg} / 1$ \\
No. 5 & Khumjung & $28 / 4 / 2013$ & $0 \mathrm{mg} / 1$ & $0 \mathrm{mg} / 1$ \\
\hline
\end{tabular}

ing that the Khumjung rockslide largely entails leucogranites further supports the hypothesis that catastrophic rock-slope failures preferentially occur in this lithology of the HHC [14]. Tectonic fault planes within these leucogranites, which were additionally found, may act as possible zones of mechanically weak discontinuities, which dip parallel or subparallel to the detachment area of Khumjung rockslide.

Occurrence of frictionite-bearing basal shear layers at Lukla clearly indicates a landslide origin of these formerly valley-blocking deposits, thus setting a minimum age constraint on the postulated extent of large valley glaciers in the Khumbu Himal.

The larger Khumjung rockslide deposit is truncated and perched $\sim 250 \mathrm{~m}$ above the gorges of the DudhKosi. Assuming that the rockslide was emplaced on the former valley floor and an average rate of bedrock river incision of $5 \mathrm{~mm} \cdot \mathrm{yr}^{-1}$ derived for the nearby Imja Khola [3], the maximum age of the rockslide is $\sim 50 \mathrm{ka}$.

The villages of Lukla (hospital), Muse, Chaurikharka, Namche Bazaar, Khumjung, Khunde (hospital), and Syangboche (airport) are situated on these two large bedrock landslides. Due to the rock failures the quality of the rock with regard to its structure, strength, porosity and permeability was significantly altered.

We state that:

i) the non-fractured and intact basement underneath the rockslide deposit acts as an aquiclude with almost no porosity;

ii) the rockslide's lower base facies acts as aquifer with little effective pore volume (due to grain size of equal to or less than $2 \mu \mathrm{m}$ to up to equal to or less than $0.63 \mathrm{~mm}$ and possibly high adhesive water content);

iii) the rockslide's higher base facies and lower "en masse" deposit acts as best aquifer (due to grain size between $0.63 \mathrm{~mm}$ and equal to or less than $6.3 \mathrm{~cm}$ );

iv) the rockslide's upper "en masse" deposit acts as seepage aquifer for both—ground- and surface mountain waters.

Thus, these two rockslide areas - around Lukla and Namche Bazaar - are highly vulnerable to ground water contamination. Drinking water sources in these areas may be contaminated by leaking landfill sites, leaking water pipes and the extensive use of agricultural fertilizers.

In Lukla, almost $50 \%$ of the landfill sites are situated on permeable rockslide material above the village and the local drinking water supply (Figure 4). Due to permeable rockslide material and a nonexistent impenetrable in-between layer (aquiclude), it is possible that landfill sites above Lukla infiltrate and contaminate water sources. Waste water and harmful contaminants from these leaking landfill sites are dissolved by rainwater during the monsoon season, and may seep into groundwater. Furthermore, the regional water supply network does not meet minimum quality requirements, as leaking plastic water pipes are laid on bare ground where rain, snow, or cattle may cause damage (Figure 12(a)).

Similar outcomes are assumed in the area of Namche Bazaar. The villages of Khumjung, Khunde and Syangboche are also situated on permeable rockslide material in the upper terrace above Namche Bazaar. It can be assumed that the underlying brecciated and strongly permeable base facies forms a perfect aquifer along their dip for leaking contaminated water, expanding from Khumjung to Namche Bazaar. Whereas no nitrate and phosphate was detectable in water samples of Khumjung, high concentrations of nitrate and phosphate were found in water samples of Namche Bazaar (Table 1). A reason for higher nutrient concentrations may be the infiltration of harmful substances such as waste water and excessive amounts of agricultural fertilizers from integrated landfill sites and agricultural fields from the upper terraces of Khumjung and Khunde. Furthermore, high concentrations of nitrate and phosphate in the water samples found in Namche Bazaar suggest southward drainage and an underground connection between the upper terrace and Namche Bazaar. 
The results of this study show that rockslide material is especially susceptible to erosion due to its high porosity and permeability. Also it can be assumed that constant rain during the monsoon season saturates the rockslide material, making it structurally weak and sensitive to erosion. Many landfill sites are at constant risk by erosion, floods, GLOFs and landslides. This is confirmed by paleostage indicators, such as lacustrine, fluvial, debris-flow and GLOF sediments, which are found throughout the valley and give evidence for severe historical events. In general, it seems that low alluvial terraces are particularly vulnerable to glacial lake outburst floods, but also to annual recurring seasonal monsoon floods. Higher alluvial terraces are supposed to be only vulnerable to larger GLOFs. Villages, settlements, agricultural land and trekking routes are situated on these terraces along the DudhKosi River. Furthermore, landfill sites are located in flood-prone areas and are at severe risk of seasonal monsoon floods and torrential rainfall events (see Figure 7). Landfill sites, which are situated too close to seasonal watercourses, streams, rivers and drinking water sources (Figure 4), contribute significantly to the degrading water quality of local water supply due to microbiological contamination and fecal pollution [22]. These findings are in agreement with previous research, which underlines that gastrointestinal infections are increasing both among local inhabitants and foreign visitors [22] [55]-[57].

As a consequence of the devastating earthquakes in April and May 2015, the Lukla and Khumjung rockslide deposit might be particularly prone to landslides and debris flows [42] [43]. It is highly possible that the stability of the shattered material is even further reduced and that its internal composition as well as its internal watercourses has been altered.

Also, this research will serve as a basis for future studies, as it has introduced many questions in need of further investigation. Further research on the environmental impacts of waste disposal in SNPBZ, in combination with the region's special geological characteristics, is required. The consequences of the earthquakes in 2015 on the rockslides need to be evaluated. More information on the disintegration of hardrock would help us to establish a greater degree of accuracy on this matter. It is suggested that the electrical conductivity of mountain waters is investigated in future studies as it correlates with rock loosening [58]. Additionally radon emanation from cataclastic rockslide material could help to detect the value of disintegration and connected permeability of rocks [59]. Profound studies on surface and groundwater pollution in rockslide material, as well as soil and air contamination due to the inappropriate treatment of hazardous waste, are necessary. Considerably more work will need to be done to determine water conductivity (i.e. by means of tracer tests). The hazard potential of glacial lake outburst floods and seasonal flooding also raises a number of questions for future research. There is a growing need for future research in order to develop feasible management plans and provide safe drinking water to the region. This should include the benefits, limitations, risks and threats which will be caused by the construction of the new road into the Khumbu valley. In road building special slope stabilization measures will be necessary in general but especially when crossing the Lukla rockslide.

\section{Conclusions}

Within this study the reciprocal interactions between landfill sites and the geo-environment were analyzed as a consequence of unsustainable tourism development in SNPBZ, Nepal.

At least two major $\left(>10^{8} \mathrm{~m}^{3}\right)$ bedrock landslides influenced the evolution of the Dudh Kosi valley and its tributaries. The facies of the bedrock landslide on the other hand indirectly conferred with waste issues.

This study has reached the following major conclusions:

1) The brecciated rockslide base facies material is particularly susceptible to erosion and porosity. Landslides, mudflows and debris-flows are observed throughout the SNPBZ due to the fragile geology and the intense monsoonal rainfall regime, posing beside GLOFs a serious risk for trails and settlements;

2) Landfill sites are often situated in exposed areas such as terraces close to river beds and active debris cones, or along the benches of alluvial terraces. They are consequentially prone to natural hazards such as lateral erosion, floods, landslides and GLOFS;

3) Landfill sites are situated close to seasonal watercourses and drainage areas in close proximity to drinking water sources, contaminating surface and ground water;

4) Rockslide material shows high porosity and permeability. It is possible that leaking landfill sites infiltrate and contaminate water sources, as there is no significant impermeable layer (aquiclude) functioning as a buffer, except the basement rock;

5) Therefore, seepage water and/or ground water (stream) in rockslide deposits is in general highly vulnerable 
to any kind of contamination.

Results have highlighted that regional infrastructure planning of landfill sites often collides with the natural features of the geo-environment and often causes harm to human health and the environment. This paper calls for a transdisciplinary approach to integrated human-environmental research, which can assist in the evolution of future waste management practices. The findings suggest several courses of action:

i) to construct solid waste disposals if possible in hardrock;

ii) to use higher not lower terraces for waste pits and landfills;

iii) to properly treat hazardous waste;

iv) to improve the supply of hygienically safe drinking water.

Although the discussion is focused on the Everest region, the implications of the results can be applied to similar areas (such as Marsyandi Valley ans Kali Gandaki Valley) with special geological characteristics and rapidly growing waste issues.

\section{Acknowledgements}

We thank MENRIS-ICIMOD for providing GIS-datasets for SNPBZ. We are grateful to Christoff Andermann and the Department of Hydrology and Meteorology of Nepal for providing data.

\section{References}

[1] Nepal, S.K. (2003) Tourism and the Environment. Perspectives from the Nepal Himalaya. Himal Books, Laltipur.

[2] Nepal, S.K. (2003) Trail Impacts in Sagarmatha (Mt. Everest) National Park, Nepal: A Logistic Regression Analysis. Environmental Management, 32, 312-321. http://dx.doi.org/10.1007/s00267-003-0049-7

[3] Barnard, P.L., Owen, L.A., Sharma, M.C. and Finkel, R.C. (2001) Natural and Human-Induced Landsliding in the Garhwal Himalaya of Northern India. Geomorphology, 40, 21-35. http://dx.doi.org/10.1016/S0169-555X(01)00035-6

[4] Bookhagen, B., Thiede, R.C. and Strecker, M.R. (2005) Abnormal Monsoon Years and Their Control on Erosion and Sediment Flux in the High, and Northwest Himalaya. Earth and Planetary Science Letters, 231, 131-146. http://dx.doi.org/10.1016/j.eps1.2004.11.014

[5] Burbank, D.W., Blythe, A.E., Putkonen, J., Pratt-Sitaula, B., Gabet, E., Oskin, M., Barros, A. and Ojha, T.P. (2003) Decoupling of Erosion and Precipitation in the Himalayas. Nature, 426, 652-655. http://dx.doi.org/10.1038/nature02187

[6] Gabet, E.J., Burbank, D.W., Pratt-Sitaula, B., Putkonen, J. and Bookhagen, B. (2008) Modern Erosion Rates in the High Himalayas of Nepal. Earth and Planetary Science Letters, 267, 482-494. http://dx.doi.org/10.1016/j.eps1.2007.11.059

[7] Galy, A. and France-Lanord, C. (2001) Higher Erosion Rates in the Himalaya: Geochemical Constraints on Riverine Fluxes. Geology, 29, 23-26. http://dx.doi.org/10.1130/0091-7613(2001)029<0023:HERITH>2.0.CO;2

[8] Vance, D., Bickle, M., Ivy-Ochs, S. and Kubik, P.W. (2003) Erosion and Exhumation in the Himalaya from Cosmogenic Isotope Inventories of River Sediments. Earth and Planetary Science Letters, 206, 273-288. http://dx.doi.org/10.1016/S0012-821X(02)01102-0

[9] Pratt-Sitaula, B., Burbank, D.W., Heimsath, A. and Ojha, T. (2004) Landscape Disequilibrium on 1000-10,000 Year Scales Marsyandi River, Nepal, Central Himalaya. Geomorphology, 58, 223-241. http://dx.doi.org/10.1016/j.geomorph.2003.07.002

[10] Barnard, P.L., Owen, L.A. and Finkel, R.C. (2006) Quaternary Fans and Terraces in the Khumbu Himal South of Mount Everest: Their Characteristics, Age and Formation. Journal of The Geological Society, 163, 383-399. http://dx.doi.org/10.1144/0016-764904-157

[11] Heimsath, A.M. and McGlynn, R. (2008) Quantifying Periglacial Erosion in the Nepal High Himalaya. Geomorphology, 97, 5-23. http://dx.doi.org/10.1016/j.geomorph.2007.02.046

[12] Munack, H., Korup, O., Resentini, A., Limonta, M., Garzanti, E., Blöthe, J.H., Scherler, D., Wittmann, H. and Kubik, P.W. (2014) Postglacial Denudation of Western Tibetan Plateau Margin Outpaced by Long-Term Exhumation. GSA Bulletin, 126, 1580-1594. http://dx.doi.org/10.1130/B30979.1

[13] Korup, O., Claque, J.J., Hermanns, R., Hewitt, K., Strom, A. and Weidinger, J.T. (2007) Giant Landslides, Topography, and Erosion. Earth and Planetary Science Letters, 261, 578-589. http://dx.doi.org/10.1016/j.eps1.2007.07.025

[14] Korup, O. and Weidinger, J.T. (2011) Rock Type, Precipation, and the Steepness of Himalayan Threshold Hillslopes. In: Geological Society, Ed., Growth and Collapse of the Tibetan Plateau, Special Publications, Geological Society, London, 235-249. http://dx.doi.org/10.1144/SP353.12 
[15] Weidinger, J.T. (2011) Stability and Life Span of Landslide Dams in the Himalayas (India, Nepal) and the Qin Ling Mountains (China). In: Evans, S.G., Hermanns, R.L., Strom, A. and Scarascia-Mugnozza, G., Eds., Natural and Artificial Rockslide Dams, Lecture Notes in Earth Sciences, Vol. 133, Springer, Berlin, 243-277. http://dx.doi.org/10.1007/978-3-642-04764-0_8

[16] Korup, O. and Tweed, F. (2007) Ice, Moraine, and Landslide Dams in Mountainous Terrain. Quaternary Science Reviews, 26, 3406-3422. http://dx.doi.org/10.1016/j.quascirev.2007.10.012

[17] Stevens, S.F. (1993) Claiming the High Ground: Sherpas, Subsistence, and Environmental Change in the Highest Himalaya. University of California Press, Berkeley.

[18] HKKH (Hindu Kush-Karakorum-Himalaya) (2009) Situation Analysis of Sagarmatha National Park and Buffer Zone. A Review of Park, Tourism Management and Stakeholder Participation, Kathmandu.

[19] Ministry of Culture, T. \& C. A. (2013) Nepal Tourism Statistics 2012. Ministry of Culture, Tourism \& Civil Aviation, Kathmandu.

[20] Spoon, J. and Sherpa, L.N. (2008) Beyul Khumbu: The Sherpa and Sagarmatha (Mount Everest) National Park and Buffer Zone, Nepal. In: Mallarach, J.M., Ed., Protected Landscapes and Cultural and Spiritual Values, KasparekVerlag, Heidelberg, 68-79.

[21] Stevens, S.F. (2003) Tourism and Deforestation in the Mt Everest Region of Nepal. The Geographical Journal, 156, 255-277. http://dx.doi.org/10.1111/1475-4959.00089

[22] Manfredi, E., Flury, B., Viviano, G., Thakuri, S., Khanal, S.N., Jha, P.C., Maskey, P.K., Kayastha, R.B., Kafle, K.R., Bhochhibhoya, S., Ghimire, N.P., Shrestha, B.B., Chaudhary, G., Giannino, F., Cartenì, F., Mazzoleni, S. and Salerno, F. (2010) Solid Waste and Water Quality Management Models for Sagarmatha National Park and Buffer Zone, Nepal. Mountain Research and Development, 30, 127-142. http://dx.doi.org/10.1659/MRD-JOURNAL-D-10-00028.1

[23] Basnet, K. (1993) Solid Waste Pollution versus Sustainable Development in High Mountain Environment: A Case Study of Sagarmatha National Park of Khumbu Region, Nepal. Contribution to Nepalese Studies, 20, 131-139.

[24] Zuser, A., Fellner, J. and Lederer, J. (2011) Final Report: Managing the Solid Waste of Sagarmatha National Park and Its Buffer Zone. Unpublished Report, University of Technology, Vienna.

[25] Anonymous (2014) Everest Region to Be Linked by Motor Road. The Kathmandupost. 11 August 2014. www.ekantipur.com/the-kathmandu-post/2014/08/11/money/everest-region-to-be-linked-by-motor-road/266061.html

[26] Weidinger, J.T., Korup, O., Munack, H., Altenberger, U., Dunning, S., Tippelt, G. and Lottermoser, W. (2014) Giant Rockslides from the Inside. Earth and Planetary Science Letters EPSL, 389, 62-73. http://dx.doi.org/10.1016/j.epsl.2013.12.017

[27] Luger, K. (2000) Kids of Khumbu. Sherpa Youth on the Modernity Trail. Mandala Book Point, Kathmandu.

[28] Gébelin, A., Mulch, A., Teyssier, C., Jessup, M.J., Law, R.D. and Brunel, M. (2013) The Miocene Elevation of Mount Everest. Geology, 41, 799-802. http://dx.doi.org/10.1130/G34331.1

[29] Osti, R., Bhattarai, T.N. and Miyake, K. (2011) Causes of Catastrophic Failure of Tam Pokhari Moraine Dam in the Everest Region. Natural Hazards, 58, 1209-1223. http://dx.doi.org/10.1007/s11069-011-9723-x

[30] Zimmermann, M., Bichsel, M. and Kienholz, H. (1986) Mountain Hazards in the Khumbu Himal, Nepal, with Prototype Map, Scale 1:50.000. Mountain Research and Development, 6, 29-40. http://dx.doi.org/10.2307/3673338

[31] Bajracharya, B., Shrestha, A. and Rajbhandari, L. (2007) Glacial Lake Outburst Floods in the Sagarmatha Region. Mountain Research and Development, 27, 336-344. http://dx.doi.org/10.1659/mrd.0783

[32] Richardson, S.D. and Reynolds, J.M. (2000) An Overview of Glacial Hazards in the Himalayas. Quaternary International, 65-66, 31-47. http://dx.doi.org/10.1016/S1040-6182(99)00035-X

[33] Schild, A. (2008) ICIMOD's Position on Climate Change and Mountain Systems. Mountain Research and Development, 28, 328-331. http://dx.doi.org/10.1659/mrd.mp009

[34] Solomon, S., Qin, D., Manning, M., Chen, Z., Marquis, M., Averyt, K.B., Tignor, M. and Miller, H.L. (2007) Contribution of Working Group I to the Fourth Assessment Report of the Intergovernmental Panel on Climate Change. Cambridge University Press, Cambridge.

[35] Byers, A. (2007) An Assessment of Contemorary Fluctations in Nepal's Khumbu Humal Using Repeat Photography. Himalayan Journal of Sciences, 4, 21-26.

[36] ICIMOD (International Centre for Integrated Mountain Development) (2007) Impact of Climate Change on Himalayan Glaciers and Glacial Lakes. Case Studies on GLOF and Associated Hazards in Nepal and Bhutan. ICIMOD, Kathmandu.

[37] ICIMOD (International Centre for Integrated Mountain Development) (2011) Glacial Lakes and Glacial Lake Outburst Floods in Nepal. ICIMOD, Kathmandu.

[38] Bolch, T., Bchroithner, M.F., Peters, J., Baessler, M. and Bajracharya, S. (2008) Identification of Glacier Motion and 
Potentially Dangerous Glacial Lakes in the Mt. Everest Region/ Nepal Using Spaceborn Imagery. Natural Hazards and Earth System Sciences, 8, 1329-1340. http://dx.doi.org/10.5194/nhess-8-1329-2008

[39] Watanabe, T., Ives, J.D. and Hammond, J.E. (1994) Rapid Growth of a Glacial Lake in Khumbu Himal, Himalaya: Prospects for a Catastrophic Flood. Mountain Research and Development, 14, 329-340. http://dx.doi.org/10.2307/3673729

[40] Thompson, S., Benn, D., Dennis, K. and Luckman, A. (2012) A Rapidly Growing Moraine-Dammed Glacial Lake on Ngozumpa Glacier, Nepal. Geomorphology, 145-146, 1-11. http://dx.doi.org/10.1016/j.geomorph.2011.08.015

[41] Cenderelli, D. and Wohl, E. (2001) Peak Discharge Estimates of Glacial-Lake Outburst Floods and "Normal" Climatic Floods in the Mount Everest Region, Nepal. Geomorphology, 40, 57-90. http://dx.doi.org/10.1016/S0169-555X(01)00037-X

[42] Götz, J., Weidinger, J.T., Kraxberger, S., Hennecke, A.-L., Buckel, J. and Adhikari, B.R. (2015) Geomorphologic and Hydrogeologic Characteristics of Populated Rockslide Deposits (Sagarmatha National Park, Khumbu Himal, Nepal). Journal of Water Resource and Protection, 7, 1038-1048. http://dx.doi.org/10.4236/jwarp.2015.713085

[43] Miehe, G. and Weidinger, J.T. (2015) Himalayan Landforms and Processes. In: Miehe, G., Pendry, C.A. and Chaudhary, R.P., Eds., Nepal-An Introduction to the Natural History, Ecology and Human Environment in the Himalayas, Royal Botanical Garden of Edinburg, Edinburg, 103-124.

[44] Weidinger, J.T. and Korup, O. (2009) Frictionite as Evidence for a Large Late Quaternary Rockslide Near Kanchenjunga, Sikkim Himalayas, India-Implications for Extreme Events in Mountain Relief Destruction. Geomorphology, 103, 57-65. http://dx.doi.org/10.1016/j.geomorph.2007.10.021

[45] Uhlir, C.F. (1998) Landslide-Dammed Lakes: A Case Study of the Lamabagar and Chaurikharka Land-Slide Deposits, Dolakha and Solukhumbu Districts, Eastern Nepal. Journal of the Nepal Geological Society, 18, 329-334.

[46] Cenderelli, D. and Wohl, E. (2003) Flow Hydraulics and Geomorphic Effects of Glacial-Lake Outburst Floods in the Mount Everest Region, Nepal. Earth Surface Processes and Landforms, 28, 385-407. http://dx.doi.org/10.1002/esp.448

[47] Conforti, M., Aucelli, P., Robustelli, G. and Scarciglia, F. (2011) Geomorphology and GIS Analysis for Mapping Gully Erosion Susceptibility in the Turbolo Stream Catchment (Northern Calabria, Italy). Natural Hazards, 56, 881-898. http://dx.doi.org/10.1007/s11069-010-9598-2

[48] Heuberger, H. and Weingartner, H. (1985) Die Ausdehnung der letzteiszeitlichen Vergletscherung an der MountEverest-Südflanke, Nepal. Mitteilungen der Österreichischen Geographischen Gesellschaft, 127, 71-80.

[49] Vuichard, D. (1986) Geological and PetrographicalInvastigations for the Mountain Hazards Mapping Project, Khumbu Himal, Nepal. Mountain Research and Development, 6, 41-52. http://dx.doi.org/10.2307/3673339

[50] Fushimi, H. (1978) Glaciation in the Khumbu Himal (2). Seppyo, 40, 71-77. http://dx.doi.org/10.5331/seppyo.40.special 71

[51] Iwata, S. (1976) Late Pleistocene and Holocene Moraines in the Sagarmatha (Everest) Region, Khumbu Himal. Seppyo, 38, 109-114. http://dx.doi.org/10.5331/seppyo.38.special 109

[52] Finkel, R.C., Owen, L.A., Barnard, P.L. and Caffee, M.W. (2003) Beryllium-10 Dating of Mount Everest Moraines Indicates a Strong Monsoonal Influence and Glacial Synchroneity throughout the Himalaya. Geology, 31, 561-564. http://dx.doi.org/10.1130/0091-7613(2003)031<0561:BDOMEM>2.0.CO;2

[53] Fort, M. (2004) Quaternary Glaciation in the Nepal Himalaya. In: Ehlers, J. and Gibbard, P.L., Eds., Quaternary Glaciation Extent and Chronology, Part III, Elsevier B.V., Amsterdam, 261-278. http://dx.doi.org/10.1016/s1571-0866(04)80132-5

[54] US Agency for International Development (2009) Healthcare Waste: Generation, Handling, Treatment and Disposal. [Online] http://www.encapafrica.org/EGSSAA/medwaste.pdf

[55] Amoruso, I., Ravazzolo, E. and Caravello, G. (2011) Water-Related Environmental Public Health in Developing Countries: Installation of a Microbiology Laboratory in the Mt. Everest National Park (Nepal) and Comprehensive Training of Local Staff. II Congresso Nazionale CUCS sulla Cooperazione Universitaria, Dept. of Environmental Medicine and Public Health, University of Padua, Padua.

[56] Ghimire, N.P., Caravello, G. and Jha, P.K. (2013) Bacterial Contamination in the Surface Waterbodies in Sagarmatha National Park and Buffer Zone, Nepal. Scientific World, 11, 94-96. http://dx.doi.org/10.3126/sw.v11i11.8560

[57] Ghimire, N.P., Jha, P.K. and Caravello, G. (2013) Water Quality of High-Altitude Lakes in the Sagarmatha (Everest) National Park, Nepal. Journal of Environmental Protection, 4, 22-28. http://dx.doi.org/10.4236/jep.2013.47A003

[58] Schramm, J.M. and Weidinger, J.T. (1996) Distribution of Electrical Conductivity at TsergoRi Landslide, CentralNorth Nepal. In: Senneset, K., Ed., Proceedings of the 7th International Symposium on Landslides, Balkema, Trondheim, Balkema/Rotterdam/Brookfield, 17-21 June 1996, 889-894.

[59] Purtscheller, F., Pirchl, T., Sieder, G., Stingl, V., Tessadri, T., Brunner, B., Ennemoser, O. and Schneider, P. (1995) 
Radon Emanation form Giant Landslides of Koefels (Tyrol, Austria) and LangtangHimal (Nepal). Environmental Geology, 26, 32-38. http://dx.doi.org/10.1007/BF00776029

[60] AGVH (Arbeitsgemeinschaft für vergleichende Hochgebirgsforschung) (1987) Shorong/Hinku-Nepal-Kartenwerk Nr. 5, 1:50.000, Munich.

[61] AGVH (Arbeitsgemeinschaft für vergleichende Hochgebirgsforschung) (1988) KhumbuHimal—Nepal-Kartenwerk Nr. 2, 1:50.000, Munich.

[62] Osti, R. and Egashira, S. (2009) Hydrodynamic Characteristics of the Tam Pokhari Glacial Lake Outburst Flood in the Mt. Everest Region, Nepal. Hydrological Processes, 23, 2943-2955. http://dx.doi.org/10.1002/hyp.7405 